https://doi.org/10.52058/2786-4952-2022-2(7)-187-199

Варнавська Інна В'ячеславівна доцент, кандидат педагогічних наук, доцент кафедри професійної освіти, Херсонський державний аграрноекономічний університет, вул. Стрітенська, б.23, м. Херсон, 73006, https://orcid.org/0000-0002-3061-0665

\title{
ВИКОРИСТАННЯ ІНТЕРАКТИВНИХ ОСВІТНІХ ТЕХНОЛОГІЙ ЯК АСПЕКТ ПІДВИЩЕННЯ ПРОФЕСІЙНОЇ КОМПЕТЕНТНОСТІ СТУДЕНТІВ
}

Анотація. За швидких темпів модернізації технологій і суспільства на перший план виходить підготовка таких випускників вишів, які мали б навички та здібності професійної адаптації у змінному світі та абсолютно нових умовах ринку праці. Освіта стає засобом для найбільш адекватного відображення вимог ринкової економіки та нового суспільства.

Зміна основ освіти супроводжується глобальним процесом таких змін, як докорінна зміна цільових орієнтирів, метод навчання, педагогічних програм і засобів, цілей і результатів. Наслідками таких метаморфоз стає зміна ролі студента і викладача, які набувають вигляду взаємин «суб'єкт - суб'єкт».

Вища професійна освіта відіграє величезну роль у формуванні майбутніх фахівців своєї галузі, тому вона повинна не тільки відтворювати інтелектуальний потенціал країни, а й забезпечувати умови формування особистості фахівця, який усвідомлює та розвиває свої здібності, готовий знайти своє місце в житті та реалізувати себе.

Важливо відзначити, що основу технології поетапного формування професійної компетентності спеціаліста в освітньому процесі вишу становлять: освітні технології із спрямованістю на розвиток творчих якостей особистості: інтегративні технології, соціально-виховні технології, технології виховання суб'єктної соціальної активності студента; педагогічні технології на основі гуманно-особистісної орієнтації педагогічного процесу; технології на основі активізації та інтенсифікації діяльності студентів (активні методи навчання): проблемне навчання (частково-пошуковий метод, технологія навчального дослідження, дослідні ігри), технології проектного навчання, інтерактивні технології (технологія проведення дискусій, диспутів); ігрові технології: педагогічні ігри, рольові та ділові ігри; технології індивідуалізованого навчання: проектний метод; технології інтеграції в освіті: інтегративні форми навчання (семінар-практикум, лекція-практикум, лекція-діалог) .

Ці технології, спрямовані на формування професійної компетентності у процесі навчально-пізнавальної, практичної, дослідницької та евристичної 
діяльності, тісно пов'язані з технологіями педагогічної взаємодії (створення ситуації успіху, оціночної діяльності, встановлення контакту з групою та ін.).

Ключові слова: заклади вищої освіти, інноваційні технології, формування професійної компетентності, освітній процес

Varnavska Inna Vyacheslavivna Associate Professor, Candidate of Pedagogical Sciences, Associate Professor of the Department of Vocational Education, Kherson State Agrarian and Economic University, Stritenska St., 23, Kherson, 73006, https://orcid.org/0000-0002-3061-0665

\section{USE OF INTERACTIVE EDUCATIONAL TECHNOLOGIES AS AN ASPECT OF IMPROVING STUDENTS 'PROFESSIONAL COMPETENCE}

Abstract. With the rapid pace of modernization of technology and society, the training of such university graduates who would have the skills and abilities of professional adaptation in a changing world and completely new labor market conditions comes to the fore. Education becomes a means to most adequately reflect the requirements of a market economy and a new society.

Changing the foundations of education is accompanied by a global process of change, such as a radical change in goals, teaching methods, pedagogical programs and tools, goals and results. The consequences of such metamorphoses are a change in the role of student and teacher, which takes the form of a relationship "subject - subject".

Higher professional education plays a huge role in shaping future professionals in their field, so it should not only reproduce the intellectual potential of the country, but also provide conditions for shaping the personality of a specialist who realizes and develops his abilities, ready to find his place in life and realize himself.

It is important to note that the basis of the technology of gradual formation of professional competence of a specialist in the educational process of higher education are: educational technologies aimed at developing creative personality traits: integrative technologies, socio-educational technologies, technologies of subjective social activity; pedagogical technologies based on the humane and personal orientation of the pedagogical process; technologies based on activation and intensification of students' activities (active teaching methods): problem-based learning (partial-search method, educational research technology, research games), project-based learning technologies, interactive technologies (technology of discussions, debates); game technologies: pedagogical games, role and business games; technologies of individualized learning: project method; technologies of integration in education: integrative forms of education (seminar-workshop, lectureworkshop, lecture-dialogue).

These technologies, aimed at the formation of professional competence in the process of educational, practical, research and heuristic activities, are closely related to the technologies of pedagogical interaction (creating a situation of success, evaluation activities, establishing contact with the group, etc.). 
Keywords: institutions of higher education, innovative technologies, formation of professional competence, educational process

Постановка проблеми. Науково-технічний прогрес, потік нової інформації, що швидко зростає, автоматизація всіх економічних сфер вимагають, щоб навчання i самонавчання в галузі інформаційних технологій стали постійними складовими професійної діяльності. Крім того, є й економічні передумови професійної комп'ютерної підготовки: зросла ціна збитків від некомпетентних рішень, що призводять до непередбачених наслідків; виникла потреба суспільства в автоматизації деяких етапів процесу навчання, у тиражуванні навчальних систем, у реалізації індивідуального навчання. Постає проблема розробки такої системи професійної підготовки, яка б сприяла розвитку мислення студентів, здатності адаптуватися до професійного середовища, забезпечуючи в результаті конкурентоспроможність випускників на ринку праці.

Тому сучасний стан освітнього процесу потребує вирішення ключових завдань. По-перше, він має бути спрямований на розвиток професійної компетентності, яка спирається на використання сучасних інформаційних засобів; по-друге, для формування професійної компетентності майбутніх випускників вишу необхідне коригування навчальних програм; по-третє, інтенсифікація та індивідуалізація процесу навчання із використанням комп'ютерних технологій, повинні застосовувати під час викладання усіх дисципліни; по-четверте, актуалізується процес розробки методики діагностики індивідуальних відмінностей студентів для створення психологічно комфортного освітнього середовища.

Аналіз останніх досліджень i публікацій. Хоча завдання розвитку професійних компетенцій розглянуті раніше в наукових доробках авторів (О.С.Віханський, І.О. Зимня, М. А. Чошанов, С. С. Шишов та ін), можна помітити, що сучасне суспільство висуває до випускників вишів нові вимоги. Інноваційна економіка, що найтісніше інтегрована 3 технологіями обробки значних обсягів інформації, задає нові умови підготовки молодих фахівців наявність необхідних знань, умінь та навичок у роботі 3 сучасними інформаційними системами і інтерактивними технологіями.

Різні питання та аспекти інформатизації навчального процесу, використання у ньому сучасних технологій розглядаються в роботах сучасних вчених (Дичківська I.M., Петрук В. А., Пометун О. І., Сисоєва С. О., Яковенко O. I. та інших). Накопичений цими авторами досвід дозволяє виділити основні напрями інформатизації вишівської освіти і розглянути можливу роль інтерактивних технологій у формуванні професійних компетенцій студентів.

Мета статті - дослідити педагогічні умови, що сприяють успішній реалізації системи професійної підготовки студентів вишу засобами інтерактивних технологій.

Виклад основного матеріалу. Вища професійна освіта відіграє значну роль у формуванні майбутніх фахівців, тому вона повинна не тільки 
відтворювати інтелектуальний потенціал країни, а й забезпечувати умови формування особистості фахівця, який усвідомлює і розвиває свої здібності, здатний знайти своє місце в житті та реалізувати себе.

Ці цільові установки на підготовку майбутнього фахівця задані в Концепції модернізації освіти, що передбачає досягнення нового рівня сучасного навчання, отримання нових освітніх результатів, формування професійної компетентності майбутнього фахівця.

Отже, компетенція - це рівень знань, умінь, навичок, досвіду діяльності, необхідний для виконання професійних обов'язків фахівця. Для того, щоб стати компетентним спеціалістом, студент повинен опанувати певні компетенції.

У тих гуманістичної парадигми освіти особливе місце посідає нині інтерактивне навчання. Інтерактивним називається таке навчання, яке засноване на психології людських взаємин і взаємодій. При застосуванні інтерактивних методів найсильніше діє на інтелектуальну активність дух змагання, суперництва, змагальності, який проявляється, коли люди колективно шукають істину. До методів інтерактивного навчання можна віднести такі: евристична розмова; дискусія; "мозкова атака"; метод «ділової гри» та інші.

На нашу думку, найефективнішими $є$ застосування ігрових освітніх технологій, адже ці технології (педагогічні ігри, рольові ігри, метод проектів), що використовуються на практичних заняттях, дозволяють максимально урізноманітнити умови діяльності, оскільки на будь-якому етапі гра розвиває здібності, створює ситуації вибору рішення і власної відповідальності за результат. Якщо всі ці елементи в ігровому проектуванні передбачені, то гра організаційно-діяльнісна, в якій необхідне дотримання всіх перерахованих ланцюжків: «потреби - цілі - самовизначення (виховання)», «норми - зміст критерії діяльності (навчання)», «здібності - методи - способи діяльності (розвиток)».

Рольові ігри використовувалися для формування різних умінь і навиків за умов, максимально наближених до реальним, з урахуванням їх відповідності таким вимогам: гра - це форма організації діяльності студентів, основа побудови гри - інтерес здобувачів, обов'язкова наявність елемента змагальності у грі.

Так, під час дослідної роботи було проведено рольову гру 3 теми «Технологія педагогічного спілкування».

Мета: розвиток різних видів професійної компетентності вчителя (гностичної, комунікативної, діалогічної, риторичної, рефлексивної та ін.).

Зміст: система практичних педагогічних завдань, що постійно ускладнюються і змінюються; взаємодія суб'єктів освітнього процесу за умов наближених до реальних; аналіз та оцінка ситуацій педагогічної взаємодії; самоаналіз та самооцінка себе як особистості на всіх етапах та у всіх видах педагогічної взаємодії.

Способи: активність студентів; рефлексивна та аналітична діяльність; оцінка та аналіз реальних педагогічних явищ. 
Результат: індивідуальний рівень розвитку різних видів професійної компетентності вчителя, усвідомлення автентичності (самоідентифікація); зміцнення системи гуманістичних ціннісних координат; оволодіння способами прийняття рішень у реальних ситуаціях професійної діяльності.

На першому етапі гри проводилося повторення теоретичного матеріалу 3 теми (сутність педагогічного спілкування, його стилі та стилі керівництва, педагогічний такт, емпатія) у формі мозкового штурму (комунікативної атаки). На другому етапі розігрувалась одна із ситуацій педагогічного спілкування 3 конфліктним змістом (на уроці економіки учень встає, збирає речі і, сказавши, що він нічого не розуміє і йому все набридло, залишає кабінет). Для вирішення цієї ситуації студентам пропонувалися ролі: учень (що залишив урок), експерти (2 студенти), директор школи, психологи (2 студенти), вчитель (4 студенти), учні (інші студенти).

Ситуація інсценувалась максимально наближено до реальних умов: відвідування директора, психолога. Через суперечності важливих моментів вирішення педагогічної завдання стали рефлексія учасників, висновки експертів. Підсумки гри були підбитті викладачем і полягали в: у всіх рольових позиціях учасників цієї гри переважало прагнення конструктивного вирішення ситуації; як методи вирішення конфлікту студентами пропонувалися емпатія, інтроспекція та логічний аналіз ситуації; причиною такої нетактовної поведінки учня є неправильно обраний стиль педагогічного спілкування вчителя.

Подібні рольові ігри були організовані у процесі вивчення таких тем, як: «Технологія педагогічного переконання», «Методи виховання», «Форми навчання» та ін., що дозволило забезпечити реалізацію особистіснодіяльнісного характеру засвоєння знань, умінь та навичок. Механізмами реалізації цієї технології стали дидактичні методи залучення студентів у творчу діяльність.

Водночас слід зазначити, що активно-діяльнісний та творчоперетворювальний етапи технології поетапного формування професійної компетентності вчителя в освітньому процесі вишу при реалізації умови створення креативного середовища вимагали цілеспрямованої роботи 3 формування естетичної компетентності студентів експериментальної групи. Це зумовлено тим, що естетика є невід'ємним елементом створення креативного середовища і однією з цінностей особистості студента, що самоактуалізується.

Тому на всіх етапах технології поетапного формування професійної компетентності вчителя кожне практичне заняття ми розпочинали з огляду педагогічних «новинок», розбору педагогічних ситуацій і виступів студентів 3 теми: «Етикет», «Мистецтво» («Поговоримо про прекрасне»). Такий організаційний момент займав 10 хвилин заняття, але значення його для самоідентифікації та самоактуалізації особистості студентів в освітньому процесі вишу і для формування професійно-педагогічної компетентності було значним: виступ із «педагогічними новинками» сприяв створенню робочої атмосфери, теми виступів значно розширювали світогляд студентів, формували 
вміння роботи 3 аудиторією і педагогічну техніку студентів. Діалог на рівні обміну думками про мистецтво сприяв діалогізації освітнього процесу, сприяв виробленню умінь слухати та чути, приймати іншу точку зору, толерантності.

В умовах морального та естетичного вакууму повідомлення студентів про великих музикантів (з музичним супроводом) та діячів мистецтва сприяли формуванню естетичної компетентності майбутніх вчителів, заснованої на вмінні сприймати прекрасне у мистецтві та житті. Така організація занять сприяла реалізації особистісного, культурологічного та аксіологічного підходу до навчання, дозволяла студентам краще пізнати один одного, розширюючи таким чином діапазон пізнання та самопізнання студентів.

3 методів стимулювання та мотивації навчально-пізнавальної діяльності студентів під час практичних занять, що використовуються в дослідноій роботі, слід виділити змагання як метод, що стимулює творчу активність, ініціативу та вдосконалює вміння працювати у колективі.

Основними організаційними принципами методу стимулювання $\epsilon$ конкретність і порівнянність показників. Кожна група або окремий студент, які беруть участь у змаганні, мають бути поставлені у рівні умови. До моментів змагання в нашій практиці відносяться: добір педагогічних «новинок», педагогічних ситуацій, ведення педагогічних щоденників тощо.

3 метою спонукання студентів до рефлексивної діяльності як важливої умови формування професійної компетентності вчителя в освітньому процесі вишу використовувався «Портфоліо» («портфель досягнень»), який кожен студент вів починаючи 3 першого етапу вивчення дисциплін педагогічного циклу. Початок цього «Портфоліо» студента було покладено на першому курсі в контексті розробленої кожним студентом програми самовиховання та самоосвіти. Важливо підкреслити, що якщо його ведення спочатку було вимогою педагога, то далі стимулом його продовження став інтерес до професійно-педагогічної діяльності та власне професійне становлення.

У комплект документів для студентських «Портфоліо» запропоновано вкласти: титульний лист, оформлений за таким планом: П.І.Б. студента, назва предмета, вид занять (лекція, семінар, практичне заняття), період створення (відповідає періоду вивчення навчальної дисципліни), П.І.Б. викладача; зміст 3 вивчених тем; короткий запис своїх успіхів, досягнень (власний аналіз); записи, конспекти доповідей, виступів, рефератів; контрольні, самостійні роботи; Ваш улюблений вид діяльності; оцінку батьків/рецензента (письмова рецензія батьків чи незалежного рецензента). Необхідно також зазначити, що поняття «професійна компетентність вчителя» стало нормою для студентів, оскільки його використання замінювало перерахування знань, умінь та навичок вчителя, дозволяючи чітко та лаконічно уявити власні досягнення; $\mathrm{i}$ вони використовували цю категорію у своїх "Портфоліо".

Для багатьох студентів аудиторні заняття стають поштовхом до усвідомлення власної автентичності, власних потреб у розвитку професійних умінь та навичок та постановки особистих завдань формування професійної 
компетентності вчителя. Вони регулярно вивчають додаткову літературу як за рекомендацією педагога, так і самостійно; аналізують різні погляди вчених на одну й ту ж педагогічну проблему; радяться щодо питань ефективності того чи того методу самовдосконалення. Орієнтацію на суб'єктність особистість неможливо уявити без розвинених рефлексивних умінь студента, оскільки рефлексія - це метакомпетентність, основний елемент професійно-педагогічної компетентності. Тому організація аналізу різних педагогічних ситуацій, самооцінка своєї навчально-пізнавальної діяльності та облік їі оцінки іншими суб'єктами освітнього процесу використовувалися кожному занятті.

Студенти із задоволенням беруть участь в організації та проведенні нетрадиційних занять, пропонують цікаві для них педагогічні ситуації та теми для обговорення. Різноманітні педагогічні завдання, на думку студентів, допомагають розвитку аналітичних, прогностичних, комунікативних, діяльнісних, конструктивних, організаторських умінь, які є ядром професійної компетентності вчителя - ключові компетентності.

Позитивно зарекомендував себе у процесі роботи над формуванням професійної компетентності фахівців в освітньому процесі вишу термінологічний підхід - нове явище у вітчизняній педагогіці, яке частково пов'язане 3 використанням можливостей інтерактивних технологій у навчанні. Сутність цього методу полягає в тому, що аналіз розуміння студентами педагогічних явищ проводився на базі їх трактування основних педагогічних понять, спеціального лексичного запасу опитуваних, оскільки нерозвинений словник тієї чи тієї галузі науки означає ii невивченість. Наприклад, після першого ознайомлення 3 поняттям «професійна компетентність», студентам пропонувалося оцінити рівень розробленості цієї наукової проблеми за такими показниками: за кількістю базових та периферійних понять; розробленості наукових визначень кожного з понять у формі розгорнутих варіантів і дефініцій; за кількістю видів аналізованої категорії; за включеністю термінів у словники та енциклопедії.

Робота у зазначеному напрямі у процесі технології поетапного формування професійної компетентності вчителя включала укладання педагогічних словників 3 вивчених тем, підготовку карток із назвами категорій та їх дефініціями, поповнення «Портфоліо» студента, використання мережі Internet для аналізу термінів тощо. 3 метою створення креативного середовища для формування професійної компетентності спеціаліста в освітньому процесі вишу в дослідній роботі (як при традиційних, так і при нетрадиційних формах роботи) використовуються елементи модульного навчання, що дозволяють активізувати навчально-пізнавальну діяльність студентів за рахунок певного структурування матеріалу, з одного боку, і основі власних форм звітності кожному за модуля, 3 іншого.

Модуль - це цільовий функціональний вузол, в якому об'єднано навчальний зміст та технологія оволодіння ним, тобто блок певних теоретичних знань, умінь та навичок їх застосування та передбачає кілька форм звітності на 
вибір студента: це може бути контрольна робота з вивченої теми, творча робота, співбесіда, тестування, участь у «круглому столі», складання словника базових понять, традиційна форма відповіді квитками тощо.

Доречним $є$ використання модулю «Загальні основи педагогіки» або «Загальна педагогіка», або «Аспекти загальної педагогіки», в якому у стислому вигляді з питаннями щодо кожного розділу можуть бути представлені такі теми: «Предмет та основні категорії педагогіки», «Основні поняття педагогіки», «Методологія та методи педагогічних досліджень», «Освітня система України», «Педагогічний процес», «Закономірності та принципи цілісного педагогічного процесу» та ін.

3 кожної теми студенти ведуть термінологічний словник, який відбиває сутність тієї чи тієї категорії; виконували завдання для самостійної роботи (назвати та дати коротку характеристику рівнів загальної та професійної освіти; порівняти категорії «педагогічний процес», «навчально-виховний процес» тощо); відповідали питання для самоконтролю.

Подібні теми модуля відображають зміст, форми та методи навчання, а також заплановані результати. Межі модуля визначаються компетентністю студента, тобто сукупністю теоретичних знань і практичних умінь та навичок, які він має продемонструвати після закінчення вивчення модуля. Перевагами використання елементів модульного навчання у дослідженні стали: активність та відносна самостійність студентів, порційність і логічна послідовність навчального матеріалу, систематичний контроль 3 подальшою корекцією, індивідуальний темп засвоєння матеріалу. Модульне навчання, що забезпечує гнучкість навчання, пристосування до індивідуальних потреб особистості та рівня іiі базової компетентності засноване насамперед на самостійній роботі студента. При цьому механізмами реалізації цього виду навчання на практиці $€$ проблемний підхід та індивідуальний темп навчання.

Створення креативного середовища на заняттях також передбачало розвиток у студентів умінь пошуку різноманітних шляхів досягнення мети, умінь використовувати метафори та аналогії для творчого пошуку, встановлення нових асоціацій та зв'язків, розвиток сприйнятливості, широти та насиченості сприйняття навколишнього світу та ін. Досягнення поставлених завдань у найбільшому сприяв пошук рішень у нестандартних ситуаціях.

У процесі формування професійної компетентності фахівців доречним $\epsilon$ використання навчально-дослідницької та науково-дослідної роботи студентів, що передбачає не просто пошук знань 3 конкретної наукової проблеми, а власний погляд на цю проблему.

Так, під час опрацювання теми «Освіта як суспільне явище та педагогічний процес» студентам можна запропонувати підготувати оригінальні проекти в мажах теми: «Кредитна система (система залікових одиниць) у практиці вищої школи», «Особливості екологічної освіти», «Освітні стандарти у контексті шкільного та вишівського навчання», «Генеза освіти як соціального явища» та ін. 
Підготовка на такі цікаві теми дозволить провести «круглий стіл», в організації та проведенні якого виявляють бажання брати участь усі студенти. За результатами «круглого столу» можна зробити такі висновки: активність та інтерес, навіть невеликий групи «заряджає» інших студентів за умови володіння ораторами технікою роботи 3 аудиторією та врахування інтересів i потреб студентського колективу; науково-дослідна діяльність учнів, спирається на вивчення та аналіз теоретичного матеріалу та підкріплення його практичною значимістю, виступає на вишівському етапі навчання одним із шляхів оволодіння педагогічними знаннями, вміннями і навичками їх застосування.

Опис технології поетапного формування професійної компетентності фахівця в освітньому процесі закладу вищої освіти було б неповним без важливого компонента - координації роботи викладачів соціально-гуманітарних дисциплін, що грунтується на знанні особливостей навчально-пізнавальної діяльності студента із врахуванням різних організаційних форм навчання, на основі яких складено пам'ятку викладача та пам'ятка студентові.

Викладачі негуманітарних дисциплін звертають увагу на низку позитивних змін як у розвитку кожного студента, так і колективу в цілому: сприятливий мікроклімат, атмосфера взаємодопомоги та взаємопідтримки, відсутність проблем 3 дисципліною, активна участь усіх студентів в обговореннях, володіння технікою виступи перед аудиторією, підвищення активності та ініціативності у студентів.

Найважливішим засобом формування професійної компетентності спеціаліста в освітньому процесі вишу є проходження виробничої практики, особливо педагогічної у школі. Значимість цього етапу для особистості студента полягає у перевірці рівня сформованості власної професійно-педагогічної компетентності у реальних умовах самостійної педагогічної діяльності. Ці умови, як показує практика, дуже часто далекі від ідеальних, очікуваних, але особливо у подоланні труднощів, в ефективній дії в нестандартних ситуаціях i виявляється професійна компетентність викладача, що складає потужну особистісну освіту та відрізняє одного студента від іншого. На зазначеному етапі студенти починають усвідомлювати, що розв'язання різного ступеню педагогічних завдань потребує значного потенціалу від викладача, всього того, що становить основу його професійної компетентності: знання, вміння, навички і досвід.

Таким чином, технологія поетапного формування професійної компетентності фахівця в освітньому процесі вишу, заснована на реалізації педагогічних умов (орієнтації на суб'єктність особистості, здатної до самоідентифікації та самоактуалізації; створення креативного середовища; спонукання до рефлексивної діяльності; діалогізації освітнього процесу) $\epsilon$ поступовим ускладненням основних завдань навчання, а також розширення арсеналу використовуваних методів та форм активної організації навчання.

Усвідомлення та прийняття проблеми професійної компетентності фахівця з перших днів навчання у виші, прагнення творчості, висока потреба у пізнанні, 
позитивна мотивація вибору професії сприяє самоактуалізації та самоідентифікації особистості. При цьому важливе значення має впевненість у власні знання, уміння і навички; суб'єктивна оцінка своїх можливостей, відкритість нового, прагнення навчатися.

Ефективність самоактуалізації особистості залежить від ефективності дидактичного процесу, що визначається адекватним вибором організаційних форм, методів і засобів навчання. Особлива роль у цьому контексті відводиться технологіям активізації та інтенсифікації діяльності студентів, активним методам навчання, що мають важливий розвиваючий ефект, серед яких дискусійні методи (групові дискусії, аналіз педагогічних ситуацій, вирішення педагогічних завдань та вправ, круглі столи) та ігрові методи (рольові ігри, ділові та педагогічні ігри, поведінковий тренінг, ігрове моделювання). Перелічені активні методи навчання сприяють самоактуалізації особистості студента за рахунок активізації пізнавальної діяльності та мисленнєвої активності, розвитку творчого мислення студентів.

Активні методи навчання, якщо вони відображають суть майбутньої професії, формують основу професійної компетентності у студентів в освітньому процесі вишу, оскільки створюють умови для відпрацювання студентами професійних навичок в умовах, наближених до ідеальним.

Важливо відзначити, що основу технології поетапного формування професійної компетентності спеціаліста в освітньому процесі вишу становлять:

- освітні технології із спрямованістю на розвиток творчих якостей особистості: інтегративні технології, соціально-виховні технології, технології виховання суб'єктної соціальної активності студента;

- педагогічні технології на основі гуманно-особистісної орієнтації педагогічного процесу;

- технології на основі активізації та інтенсифікації діяльності студентів (активні методи навчання): проблемне навчання (частково-пошуковий метод, технологія навчального дослідження, дослідні ігри), технології проектного навчання, інтерактивні технології (технологія проведення дискусій, диспутів);

- ігрові технології: педагогічні ігри, рольові та ділові ігри;

• технології індивідуалізованого навчання: проектний метод;

- технології інтеграції в освіті: інтегративні форми навчання (семінарпрактикум, лекція-практикум, лекція-діалог) .

Ці технології, спрямовані на формування професійної компетентності у процесі навчально-пізнавальної, практичної, дослідницької та евристичної діяльності, тісно пов'язані з технологіями педагогічної взаємодії (створення ситуації успіху, оціночної діяльності, встановлення контакту з групою та ін.). Рівень необхідних формування професійної компетентності вчителя знань, умінь і навиків кожному етапі навчання постійно зміняться, як i ̈̈х зміст. Відбувається поступове ускладнення і розвиток кожного вміння, зміна та розширення його обсягу, перехід від репродуктивної до частково-пошукової, проблемної, дослідницької та творчої (креативної) діяльності, що відображає 
сутність технології поетапного формування професійної компетентності вчителя в освітньому процесі ЗВО.

Кожний етап технології формування професійної компетентності набуває якісно нового характеру: на адаптаційно-репродуктивному етапі 3 метою орієнтації на суб'єктність особистості, здатної до самоактуалізації та самоідентифікації здійснюється залучення студентів до навчально-пізнавальної діяльності з урахуванням їх інтересів та здібностей (пропонувалися різні теми рефератів i доповідей). Це сприяє формуванню i розвитку умінь студентів виконувати всі види та форми навчально-пізнавальної діяльності (слухати та записувати лекції, конспектувати літературу, виступати перед аудиторією, брати участь у дискусії, надавати аналітичну оцінку явищам та ситуаціям тощо), що стало суттєвим показником студента як суб'єкта навчальної діяльності у освітньому процесі вишу.

На активно-діяльнісному етапі технології формування професійної компетентності з метою реалізації першої умови в освітньому процесі вишу створюються умови, які наближені до реальних, спрямовані на формування умінь студентів у процесі засвоєння педагогічної діяльності розв'язувати нові завдання, професійних ситуацій, ефективно діяти у нестандартних умовах, які визначають появу низки суперечностей, які у ролі рушійних сил розвитку особистості майбутнього фахівця. I, нарешті, на творчо-перетворювальному етапі, що супроводжується практичною діяльністю, виявлялися їх вміння планувати, організовувати свою діяльність, спілкуватися, конструктивно вирішувати різні педагогічні ситуації, тобто ступінь самоактуалізації та самоідентифікації особистості як суб'єкта професійно-педагогічної діяльності.

Створення креативного середовища в освітньому процесі вишу на всіх етапах технології формування професійної компетентності грунтувалося на відносинах взаєморозуміння, взаємопідтримки, відсутності конфліктів. Посилення креативного середовища здійснювалося за рахунок залучення студентів у науково-дослідницьку діяльність, орієнтацію для проведення творчої роботи на виробництві, що було спрямовано досягнення студентами високого рівня творчої активності та пізнавальної самостійності, незалежності, оволодіння творчими вміннями i навичками. Для посилення мотивації діяльності, активізації творчих здібностей студентів та стимулювання самостійності у прийнятті рішень нами використовувалися такі педагогічні технології активного навчання: колективної та групової взаємодії (дискусії, технологія взаємонавчання, робота в групах змінного складу), технології імітаційного моделювання основних рис реальної діяльності професіонала (рольові, ділові ігри, проектування, аналіз педагогічних ситуацій, вирішення різноманітних педагогічних завдань), технології трансформації контексту професійної ситуації у контекст життєвої та навчальної ситуації студента (створення у навчальному процесі реальних ситуацій - аналогів практичної педагогічної діяльності). 
Журнал«Герспективитаінновації наукиљ

(Серія«Гедагогіка», Серія«Гцихологія», Серія«Медицинв»

№2(7) 2022

Висновки. Застосування активних та проблемних методів навчання дозволило сформувати у студентів установку на самостійне відкриття нового знання, посилюючи при цьому віру у власні креативні здібності.

При цьому важливою умовою успішного формування професійної компетентності є спонукання до рефлексивної діяльності з метою реалізації якого студентам 3 перших днів навчання у закладі вищої освіти було запропоновано вести «Портфоліо», значення якого полягало у розвитку рефлексивних умінь, спрямованих на свідомий контроль результатів навчальнопізнавальної діяльності та рівня власного професійного розвитку. Особлива увага на всіх етапах технології формування професійної компетентності приділялася суб'єктивній оцінці особистісних досягнень, а також вмінню студентів адекватно оцінювати продуктивність діяльності всіх суб'єктів освітнього процесу вишу. Слід зазначити, що розвиток рефлексивних умінь студентів проходило поступово: якщо на адаптаційно-репродуктивному етапі студенти оцінювали змістовність виступів однокурсників, то на активнодіяльнісному етапі вони аналізували змістовність виступу, педагогічну техніку промовця, ступінь представленості власної точки зору. На творчоперетворювальному етапі студенти прагнули співвіднести матеріал, що вивчається, 3 власним життєвим і професійним досвідом, аналізуючи різні аспекти тієї чи тієї педагогічної проблеми. Діалогізація освітнього процесу також характеризувалася переходом від діалогу із собою (ведення «Портфоліо» студента, педагогічних щоденників) до діалогу з іншими суб'єктами освітнього процесу вишу на основі поступового формування готовності до діалогу. На кожному етапі технології формування професійної компетентності створювалися умови для діалогічної взаємодії суб'єктів освітнього процесу за рахунок навчання студентів правилам ведення бесіди, диспуту, дискусії та їх подальшого практичного відпрацювання. При цьому важливим компонентом технології є моніторинг формування аналізованого феномену, що передбачає діагностику та результат продуктивності зазначеного процесу.

\section{Лimepamypa:}

1. Варнавська І.В. Аспекти застосування інноваційних методів навчання при викладанні економічних дисциплін // Таврійський науковий вісник. Серія: Економіка: Науковий журнал. Вип. 5. Херсон: Видавничий дім «Гельветика», 2021. С.104-112.

2. Дичківська I.M. Інноваційні педагогічні технології. Навчальний посібник. Київ: Академвидав, 2004. 352 с.

3. Петрук В. А. Теоретико-методичні засади формування професійної компетентності майбутніх фахівців технічних спеціальностей у процесі вивчення фундаментальних дисциплін : моног. Вінниця : УНІВЕРСУМ-Вінниця, 2006. 292 с.

4. Пометун О. І. Інтерактивні методики та система навчання. Київ: Шкільний світ, 2007. $112 \mathrm{c}$.

5. Сисоєва С. О. Інтерактивні технології навчання дорослих: навчально-методичний посібник. Київ: ВД«ЕКМО», 2011. 324 с.

6. Яковенко О. I. Формування компетенцій професійної діяльності економістів у процесі практичної підготовки: навч.-метод. посіб. Ніжин : Видавець ПП Лисенко М. М., 2014. 184c. 


\section{References:}

1. Varnavs'ka I.V. (2021) Aspekty zastosuvannya innovatsiynykh metodiv navchannya pry vykladanni ekonomichnykh dystsyplin [Aspects of application of innovative teaching methods in teaching economic disciplines]. Tavriys'kyy naukovyy visnyk. Seriya: Ekonomika: Naukovyy zhurnal - Tavriya Scientific Bulletin. Series: Economics: Scientific Journal. Vyp. 5. Kherson: Vydavnychyy dim «Hel'vetyka», 2021. 104-112. [in Ukrainian].

2. Dychkivs'ka I.M. (2004) Innovatsiyni pedahohichni tekhnolohiyi [Innovative pedagogical technologies]. Kyiv: Akademvydav. [in Ukrainian].

3. Petruk V.A. (2006). Teoretyko-metodychni zasady formuvannya profesiynoyi kompetentnosti maybutnikh fakhivtsiv tekhnichnykh spetsial'nostey u protsesi vyvchennya fundamental'nykh dystsyplin [Theoretical and methodological principles of formation of professional competence of future specialists of technical specialties in the process of studying fundamental disciplines]. Vinnytsya : UNIVERSUM-Vinnytsya. [in Ukrainian].

4. Pometun O.I. (2007) Interaktyvni metodyky ta systema navchannya [Interactive methods and learning system]. Kyiv: Shkil'nyy svit. [in Ukrainian].

5. Sysoyeva S.O. (2011) Interaktyvni tekhnolohiyi navchannya doroslykh [Interactive technologies of adult learning]. Kyiv: $\mathrm{VD} \ll \mathrm{EKMO} » /$ [in Ukrainian].

6. Yakovenko O.I. (2014) Formuvannya kompetentsiy profesiynoyi diyal'nosti ekonomistiv u protsesi praktychnoyi pidhotovky [Formation of competencies of professional activity of economists in the process of practical training]. Nizhyn : Vydavets' PP Lysenko M. M. [in Ukrainian]. 